\title{
INFLUENCE OF POLYMER FERTILIZER ON YIELD OF POTATOES IN THE NORTH-WEST RUSSIA
}

\author{
Aleksey Komarov ${ }^{1}$, Andrey Ivanov ${ }^{1}$, Ivan Sokolov ${ }^{1}$, Andrey Komarov ${ }^{2}$ \\ ${ }^{1}$ Leningrad Scientific Research Institute of Agriculture 'Belogorka', Russia \\ ${ }^{2}$ Agrophysical Institute, Russia \\ sfliga17@gmail.com
}

\begin{abstract}
New types of polymer fertilizer series 'Vitanoll' are used in adaptive-varietal agro technology in the cultivation of seed potatoes. The experiments were conducted on sod-podzolic soils, typical of the North-West region of the Russian Federation. The aim of the research was to study the effect of new polymer fertilizers on potato yield. Research tasks included assessing the effect of various polymer fertilizers (Polymer-N, Polymer-P, Polymer-K.), as well as the effect of Polymer-N on different potato varieties. Based on the studies conducted, the most responsive potato varieties to polymeric fertilizers with nitrogen were identified. They turned out to be Salin (increase of $7.1 \mathrm{t} \mathrm{ha}^{-1}$ ) and Mocart (increase of $4.1 \mathrm{t} \mathrm{ha}^{-1}$ ). Evaluation of the influence of different types of polymer fertilizers revealed that the most effective are polymer fertilizers with potassium.
\end{abstract}

Key words: polymer fertilizers, foliar plant nutrition, organic-mineral complexes, resource-saving adaptive-landscape farming.

\section{Introduction}

The positive effects of potato fertilizers are wellknown (Holm \& Nylund, 1978; Misgina, Kebede, \& Alle, 2013). However, nutrients from mineral fertilizers are used by no more than $50 \%$. To increase the efficiency of nutrient utilization from fertilizers, in recent years the Russian scientists have developed a fundamentally new class of fertilizers suitable for use as high-performance foliar plant nutrition. We are talking about liquid complex polymer fertilizers. These fertilizers are fundamentally different from the traditional means used for foliar plant nutrition. Importance of the difference lies in the fact that significant amounts of nitrogen (up to 25\%), phosphorus (up to $25 \%$ ) and potassium (up to $15 \%$ ) contained in the new fertilizers are not aqueous solutions of mineral salts, but are in the form of organicmineral complexes fixed on the polymer matrix. The organic polymer, which is the basis of fertilizers, possesses surface-active and adhesive properties in relation to the surface of the leaf plate, shoot, and stalk and is able to deposit, and then prolongedly supply the vegetative plant with nutrients.

A distinctive feature of the new fertilizers is a strictly constant chemical composition, which favorably distinguishes them from many compounds of irregular composition used for these purposes. In addition, due to the peculiarities of their structure, such fertilizers are fundamentally different in their properties from aqueous solutions of salts, which until now have been used for foliar dressings. In particular, they have the following important agrotechnical features: allow you to effectively feed, regardless of acidity and soil composition (do not acidify the soil, do not affect the microbiocenoses formed in the soil); provide a soft prolonged action; are not afraid of freezing; allow the use of water of any hardness. But most importantly, they are resistant to precipitation and wind erosion. That is, being applied to the plants they are not washed off with water and not blown away by the wind, and are resistant to insolation. Thus, one of the most significant properties of the new polymer fertilizers, distinguishing them from other previously used for foliar feeding, is their resistance to the effects of various meteorological factors. This resistance will be decisive for growing crops in adverse weather conditions.

It was previously shown that polymer fertilizers are $100 \%$ used by the plant (Nayda, Komarov, \& Petropavlovsky, 2010; Osipov, Shkrabak, \& Suvorov, 2013; Shkrabak, 2011). However, the effectiveness of these fertilizers in the cultivation of potatoes has not been studied yet. In order to study the effect of new polymer fertilizers on potato yields, relevant experiments have been carried out. While the experiments have been carried out only in the conditions of the North-West of Russia, it is possible to adapt the research data to other conditions.

The purpose of the research was to study the effect of new polymer fertilizers on potato yield in the conditions of the North-West of the Russian Federation.

Research tasks:

1. Assess the effects of polymer fertilizer (polymer-N) on different varieties of potatoes, including: Nevskii-standard, Mocart, Red Lady, Courage, Sifra, Salin, Desire, Serafima;

2. Assess the effect of various polymeric fertilizers on potato yield, including: Polymer-N, Polymer-P, Polymer-K.

\section{Materials and Methods}

One of the first polymer fertilizers was the polymer complex of trace elements - Akvadon-Micro 
(Shkrabak, 2011). Then polymeric fertilizers enriched with macroelements were developed: fertilizers of the Zelenit (Osipov, Shkrabak, \& Suvorov, 2013) and Kora (Nayda, Komarov, \& Petropavlovsky, 2010). Finally, in addition to plant nutrition elements have been added to the polymer matrix: tools to control their use, means of penetration and fixation in plant tissues, hormonal and enzyme regulators, humates and other natural metabolites; thus, 'Vitanoll' series polymeric fertilizers were obtained (Komarov Andrey \& Komarov Aleksey, 2018). In such a way, complex agro-adaptogens of the KAA series were developed. The basis of these fertilizers was an organic polymer matrix with the inclusion in the composition of the polymer not only the necessary nutrients, but also various means that ensured a complex effect of action at a synergistic level.

New types of polymer fertilizers can find their application in different directions, one of the most promising is the use in adaptive-varietal agrotechnology, for example, in the cultivation of seed potatoes. To assess the effect of polymer fertilizers on potato yield, field experiments were conducted. The first experiment was conducted in the conditions of 'Agrotechnika' CJSC of the Tosnensky District of the Leningrad Region. The experiment was carried out at the seed-growing site, where different varieties were introduced from different regions by the leading potato producers. The experiments were carried out based on the method of ecological strain testing. The coordinates of the experimental field are $59^{\circ} 30^{\prime}-$ $599^{\circ} 32$ 'north latitude and $31^{\circ} 18^{\prime}-31^{\circ} 20^{\prime}$ ' east longitude. The soil is highly cultivated sod-podzolic with an organic matter content of $5.2 \%, \mathrm{pH}_{\mathrm{KCl}}-$ 5.8, $\mathrm{K}_{2} \mathrm{O}-290 \mathrm{mg} \mathrm{kg}^{-1}, \mathrm{P}_{2} \mathrm{O}_{5}-460 \mathrm{mg} \mathrm{kg}^{-1}$.

Another experiment was carried out in the selection and seed production of $\mathrm{OPH}$ potatoes 'Kalozhitsy', Volosovsky District, Leningrad Region. Field experiments were performed on sod-carbonate medium loamy soil. The coordinates of the landfill are $59^{\circ} 25^{\prime}-59^{\circ} 26^{\prime}$ 'north latitude and $29^{\circ} 04^{\prime}-29^{\circ} 05^{\prime}$ ' east longitude. The soils of the experimental plots were characterized by a low content of nutrients. Thus, the content of mobile phosphorus $\mathrm{P}_{2} \mathrm{O}_{5}$ was in the range of $300-375 \mathrm{mg} \mathrm{kg}^{-1}$, and the content of exchangeable potassium $\mathrm{K}_{2} \mathrm{O}-260-315 \mathrm{mg} \mathrm{kg}^{-1}$. The humus content was low - up to $2.06 \%$. The soils had a pH characteristic of $6.4-6.6$, which is typical of this type and is close to neutral. Hydrolytic acidity was in the range of $0.81-1.08$, the amount of exchange bases $15-26 \mathrm{mmol}$ per $100 \mathrm{~g}$ of soil. In general, the soil was characterized by a low level of cultivation.

\section{Results and Discussion}

Agro-technology was standard for cultivating seed crops of the super-super elite class, with the difference that part of the experimental field in all varieties for the width of one sprayer boom $(6.5 \mathrm{~m})$ was treated with the 'Polymer-N' preparation with a dose of 200 $1 \mathrm{ha}^{-1}$ at a solution concentration $2 \%$. Processing of plants was carried out in the evening hours (after 21 hours) according to vegetative plants at the beginning of flowering plants.

Harvesting was done by hand on the plots. The yield of 5-10 typical bushes was estimated from each experimental plot. For each bush, the weight and amount of standard (more than $100 \mathrm{~g}$ ) and nonstandard (less than $50 \mathrm{~g}$ ) products were taken into account. Accounting was carried out in 3 replicates.

The yield of the crop (Table 1) varied from 29.0 to $41.1 \mathrm{t} \mathrm{ha}^{-1}$ by varieties in the control (background seed production) and from 32.1 to $47.2 \mathrm{t} \mathrm{ha}^{-1}$ when processed by Polymer-N.

Based on the experiment, it was revealed that the introduced potato varieties, different in their precocity and physiological and biochemical characteristics, responded differently to the treatment with Polymer-N. Thus, varieties that have a more extended vegetation period and a less adaptive reaction, reacted to the treatment with a bookmark of additional stolons (Mozart, Red Lady, Courage). However, a limited growing season did not allow them to form all fullfledged tubers. A significant part of tubers, from 24 to $32.2 \%$ relative to the control, was formed in the form of small tubers (less than $50 \mathrm{~g}$ ). The latter reflects that the processing of these varieties was not carried out in accordance with the optimum, when the outflow of nutrients needed to be sent to reproductive or spare organs (in this case, tubers). It is possible that for these varieties it was necessary to carry out additional processing with other polymeric fertilizers, for example, containing not only nitrogen, but also phosphorus with potassium, thereby giving them the opportunity to realize the potential introductory potential.

On the contrary, those varieties that adaptively reacted to the treatment formed mainly the main (large-fruited) products, where the average size of standard tubers was 100 - $150 \mathrm{~g}$ (Nevsky, Serafima, Desire, Salin, Sifra).

Thus, the drug 'Polymer-N' had an effective impact on the productivity of all the studied varieties, increasing the yield relative to the basic economic agro-technology by an average of $10-15 \%$. Of particular interest is the specificity of the reaction of potato varieties to the use of the drug. The latter points to the need to develop adaptive-grade technology of precision farming, both when introducing new introduced varieties into the culture and to develop the foundations of resourcesaving adaptive-landscape farming.

The study of the influence of various polymeric fertilizers on the yield and crop structure of different varieties of potatoes was carried out in the aspect of 


\section{Reaction of different potato varieties to the treatment of vegetative plants with the preparation 'Polymer-N'}

\begin{tabular}{|c|c|c|c|c|c|c|}
\hline \multirow[b]{2}{*}{ Version } & \multicolumn{3}{|c|}{ Productivity, $\mathrm{t} \mathrm{ha}^{-1}$} & \multicolumn{3}{|c|}{ Increment, $\%$} \\
\hline & Total & Standard & Not standard & Total & $\begin{array}{c}\text { Standard (large and } \\
\text { medium tubers) }\end{array}$ & $\begin{array}{c}\text { Not standart } \\
\text { (small tubers) }\end{array}$ \\
\hline \multicolumn{7}{|c|}{ Variety Mocart } \\
\hline Background & 29.0 & 25.9 & 3.1 & & & \\
\hline $\begin{array}{l}\text { Background } \\
+ \text { Polymer-N }\end{array}$ & 32.1 & 28.0 & 4.1 & +11 & +8 & +32 \\
\hline \multicolumn{7}{|c|}{ Variety Red Lady } \\
\hline Background & 38.8 & 36.5 & 2.3 & & & \\
\hline $\begin{array}{l}\text { Background } \\
+ \text { Polymer-N }\end{array}$ & 42.2 & 39.2 & 3.0 & +9 & +7 & +30 \\
\hline \multicolumn{7}{|c|}{ Variety Courage } \\
\hline Background & 37.8 & 32.8 & 5.0 & & & \\
\hline $\begin{array}{l}\text { Background } \\
+ \text { Polymer-N }\end{array}$ & 41.2 & 35.0 & 6.2 & +9 & +7 & +24 \\
\hline \multicolumn{7}{|c|}{ Variety Sifra } \\
\hline Background & 32.8 & 26.0 & 6.8 & & & \\
\hline $\begin{array}{l}\text { Background } \\
+ \text { Polymer-N }\end{array}$ & 35.0 & 30.0 & 5.0 & +7 & +15 & -26 \\
\hline \multicolumn{7}{|c|}{ Variety Salin } \\
\hline Background & 41.1 & 36.0 & 5.1 & & & \\
\hline $\begin{array}{l}\text { Background } \\
+ \text { Polymer-N }\end{array}$ & 47.2 & 43.1 & 4.1 & +15 & +20 & -20 \\
\hline \multicolumn{7}{|c|}{ Variety Desire } \\
\hline Background & 38.7 & 29.5 & 9.2 & & & \\
\hline $\begin{array}{l}\text { Background } \\
+ \text { Polymer-N }\end{array}$ & 40.3 & 31.8 & 8.5 & +4 & +8 & -8 \\
\hline \multicolumn{7}{|c|}{ Variety Serafima } \\
\hline Background & 41.1 & 30.8 & 10.3 & & & \\
\hline $\begin{array}{l}\text { Background } \\
+ \text { Polymer-N }\end{array}$ & 39.5 & 31.5 & 8.0 & -4 & +2 & -22 \\
\hline \multicolumn{7}{|c|}{ Variety Nevskii - standard } \\
\hline Background & 40.6 & 32.6 & 8.0 & & & \\
\hline $\begin{array}{l}\text { Background } \\
+ \text { Polymer-N }\end{array}$ & 45.5 & 38.6 & 6.9 & +12 & +18 & -14 \\
\hline
\end{tabular}

ecological variety testing. Environmental testing, raised to a new technological and methodological level, reveals the prospect of further growth of plant productivity (at the level of varieties) and allows for more efficient use of fertilizers and other means of chemicalization under production conditions. Crop accounting was carried out by accounting sites for $10-20$ bushes from each option in 3 times, yield data are presented in Table 2. Studies were conducted with potato varieties Nevsky.

The results of the experiment presented in the table demonstrate the different efficacy of polymeric fertilizers when they process vegetative plants. Thus, the processing of nitrogen-containing 'Polymer-N' contributed to a slight increase in yield (by $2.1 \mathrm{t} \mathrm{ha}^{-1}$ or $7 \%$ to the corresponding background - control). Fertilizer 'Polymer-P' provided a large increase (up to $3.7 \mathrm{tha}^{-1}$ or by $12 \%$ to the control). The high efficacy of the drug is probably due to the positive effect of phosphorus and potassium in its composition.

Indeed, the vegetative mass of potato plants was processed at the flowering stage, when the culture demand for nitrogen decreases and the demand for phosphorus and potassium increases. Taking into account the fact that the potato is a potassium dependent culture, then the processing of plants with potassium-containing 'Polymer-K' provided the highest yield increase (by $4.9 \mathrm{t} \mathrm{ha}^{-1}$ or $15 \%$ to 


\section{The effect of polymeric fertilizers on potato yield}

\begin{tabular}{|l|c|c|c|}
\hline \multirow{2}{*}{\multicolumn{1}{c|}{ Version }} & \multicolumn{2}{c|}{ Yield } & \multicolumn{2}{c|}{ Increase control } \\
\cline { 2 - 4 } & $\mathrm{t} \mathrm{ha}^{-1}$ & $\mathrm{t} \mathrm{ha}^{-1}$ & 100 \\
\hline Control & 32.0 & 0.0 & 7 \\
\hline Polymer-N & 34.1 & 2.1 & 12 \\
\hline Polymer-P & 35.7 & 3.7 & 15 \\
\hline Polymer-K & 36.9 & 4.9 & \multicolumn{3}{|c}{$3.7 \mathrm{t} \mathrm{ha}^{-1}$} \\
\hline Statistics: the smallest significant difference $\left(\mathrm{SSD}_{05}\right)$ & \multicolumn{3}{|c}{} \\
\hline
\end{tabular}

the corresponding background). The high efficiency of potash supplementation can be attributed to the potash deficiency in the soil due to the abundance of precipitation of the season, which ensures the migration of water-soluble forms of potassium to the lower soil horizons (the latter was confirmed by the data of tissue diagnostics).

The results of the study were statistically interpreted using the criterion of significance, which takes into account such a basic statistical indicator as the smallest significant difference $\left(\mathrm{SSD}_{05}\right)$. Statistical calculations were done on the basis of analysis of variance adopted for assessing the accuracy of field experiments on Dospehov (Dospehov, 1985).

The data obtained in the experiments are consistent with the results presented by other researchers (Holm \& Nylund, 1978; Misgina, Kebede, \& Alle, 2013), where the highest effectiveness of potash fertilizers for potatoes was shown. In our experiments, the highest efficacy of polymer fertilizers with potassium was also shown. At the same time, the specificity of the varietal reaction of potatoes to polymer fertilizers was also revealed. These studies have been carried out so far only in the conditions of the North-West region of the Russian Federation. The authors hope to attract scientists and practitioners of agricultural production to study jointly the effectiveness of new polymer fertilizers in other countries, since science has no limits.

\section{Conclusions}

Polymer fertilizers effectively acted on the growth and development of potatoes, providing an increase in yield from 6 to $15 \%$ given the corresponding background. At the same time, various fertilizers, due to the nutrients contained in them, had different effects on the development of potatoes in the critical phase of ontogenesis.

To ensure the efficient use of polymer fertilizers, it is advisable to consider both their dose and targeted delivery to the necessary phase of crop development. To do this, it is necessary to develop a new technology of potato cultivation, based on optimizing the nutritional regime of plants using polymer fertilizers.

\section{References}

1. Dospehov, B. (1985). Methods of field experience (with the basics of statistical processing of research results). Moscow: Agropromizdat.

2. Holm, D., \& Nylund, R. (1978). The influence of potassium fertilizer application on tuber yield and mineral element content of potato petioles during the growing season. American Potato Journal. 55(5), $265-273$. DOI: $10.1007 / \mathrm{BF} 02852135$.

3. Komarov, A., \& Komarov, A. (2018). Перспективы использования комплексных агрохимикатов для дифференцированного их внесения в качестве средств управления ростом и развитием растений (Prospects for the use of complex agrochemicals for their differentiated introduction as a means of controlling the growth and development of plants). Agrochemical Bulletin. No. 6, 34-38. DOI: 10.24411/0235-25162018-10057. (in Russian)

4. Misgina, N., Kebede, F., \& Alle, E. (2013). Effect of fertilizers on yield and yield component of potato. LAP Lambert Academic Publishing.

5. Nayda, N., Komarov, A., \& Petropavlovsky, А. (2010). Перспективы использования новых полимерных удобрений 'Зеленит' при культивировании козлятника лекарственного (Prospects for the use of new polymer fertilizers 'Zelenit' in the cultivation of medicinal kozlyatnika). Izvestia SPbAU. No. 19, 14-20. (in Russian)

6. Osipov, A., Shkrabak, T., \& Suvorov, D. (2013). Применение полимерно-хелатных микроудобрений 'Аквадон-микро' и 'Кора-N' на посевах озимых и яровых культур (Use of polymer chelated micronutrients 'Aquadon-micro' and 'Bark-N' on winter and spring crops). Izvestia SPbAU. No. 30, 6468. (in Russian) 
7. Shkrabak, E. (2011). Эффективность удобрения Аквадон-Микро//Защита и карантин растений (Тhе effectiveness of fertilizer Aquadon-Micro//Protection and quarantine of plants). Protection and quarantine of plants. No. 3, 26. (in Russian) 